DOI: https://doi.org/10.47405/mjssh.v6i6.832

\begin{tabular}{|c|c|}
\hline 4.581 & Malaysian Journal of Social Sciences and Humanities (MJSSH) \\
\hline $\begin{array}{l}\text { Malaysian Journal of } \\
\text { Social cciences and }\end{array}$ & Volume 6, Issue 6, June 2021 \\
\hline (MJ-SSH) & e-ISSN: 2504-8562 \\
\hline & $\begin{array}{l}\text { Journal home page: } \\
\text { www.msocialsciences.com }\end{array}$ \\
\hline
\end{tabular}

\title{
Masalah Sekuriti Makanan Sebelum dan Semasa Pandemik Covid-19: Kajian kes di New Zealand
}

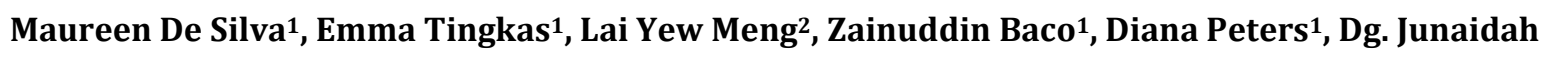 \\ Awang Jambol1 \\ 1Fakulti Sains Sosial dan Kemanusiaan, Universiti Malaysia Sabah (UMS) \\ 2Pusat Penataran Ilmu dan Bahasa, Universiti Malaysia Sabah (UMS)
}

Correspondence: Maureen De Silva (maureend@ums.edu.my), Lai Yew Meng (lyewmeng@ums.edu.my)

\begin{abstract}
Abstrak
Kajian ini bertujuan untuk menelusuri dinamika masalah sekuriti makanan yang berlaku di kalangan rakyat sebelum dan semasa pandemik Covid-19. Berlandaskan kepada kajian kes ke atas negara New Zealand, kajian ini akan merungkaikan isu sekuriti makanan yang dialami oleh rakyat New Zealand dalam tempoh dua dekad kebelakangan ini dan impak pandemik Covid-19 ke atas masalah sekuriti makanan di kalangan rakyat. Kajian ini mendapati bahawa dalam tempoh 20 tahun ini, sebilangan penduduk New Zealand sudah berhadapan dengan isu akses kepada makanan terutamanya golongan etnik Maori dan Pasifik, gelandangan, kanak-kanak, ibu/bapa tunggal, dan orang kurang upaya. Mereka berhadapan dengan isu tidak cukup makanan yang antaranya menjejaskan nutrisi, kestabilan mental dan hubungan kekeluargaan. Masalah sekuriti makanan yang dihadapi oleh rakyat New Zealand diperburukkan lagi apabila berlakunya pandemik Covid-19 pada akhir tahun 2019. Pandemik ini bukan sahaja telah mencetuskan krisis kesihatan tetapi ia juga telah menyebabkan krisis ekonomi yang bersama-samanya menimbulkan ancaman terhadap sekuriti makanan di kalangan ramai lagi rakyat New Zealand. Antaranya, pandemik Covid-19 telah menjejaskan akses kepada makanan dari segi ketiadaan sumber pendapatan mencukupi untuk membeli makanan kerana lockdown atau dibuang kerja; gangguan kepada sistem rantaian bekalan bila berlakunya kekurangan produk penting disebabkan oleh pembelian panik dan masalah pembungkusan; kenaikan harga barangan terutamanya sayuran dan buah-buahan segar yang menjejaskan pengambilan nutrisi; dan penutupan bank makanan serta perniagaan kecil semasa tempoh lockdown kerana tidak dikategorikan sebagai essential. Kajian ini menggunakan pendekatan analisis sejarah berdasarkan penggunaan sumber primer (khususnya dokumen, laporan, akhbar) dan sumber sekunder.
\end{abstract}

Kata kunci: sekuriti makanan, masalah sekuriti makanan, pandemik Covid-19, New Zealand

\section{Food Insecurity Issued Before and During the Covid-19 Pandemic: A Case Study of New Zealand}

\begin{abstract}
This study aims to trace the dynamics of food insecurity in New Zealand before and during the outbreak of the Covid-19 pandemic. Based on a case study of New Zealand, this study attempts to analyse issues of food insecurity experienced by New Zealanders over the past two decades and to what extent did the current Covid-19 pandemic exacerbate food insecurity among the people. The
\end{abstract}


study finds that during the past twenty years, a proportion of New Zealanders had faced problems of access to food, especially the Maori and Pacific ethnic groups, the homeless people, children, single parents, the disabled etc. They were faced with insufficient food which among others affects nutrition, mental stability and family relationships. Food insecurity faced by New Zealanders were exacerbated by the outbreak of the Covid-19 pandemic in late 2019. The pandemic has not only triggered a health crisis, but it has also caused an economic crisis that together posed a threat to food security among many more New Zealanders. Among others, the Covid-19 pandemic has affected access to food due to insufficient income to buy food during lockdowns and layoffs; disruption to supply chain systems with the shortage of essential products due to panic buying and packaging problems; rising prices of goods notably fresh vegetables and fruits which compromised intake of nutrition; and the closure of nonprofit, non-essential food charities and small food businesses during lockdown. This study uses a historical analysis approach based on the use of primary sources (especially documents, reports, newspapers) and secondary sources.

Keywords: food security, food insecurity, Covid-19 pandemic, New Zealand

\section{Pengenalan}

Sekuriti makanan boleh ditakrifkan sebagai keadaan di mana setiap individu mempunyai akses fizikal, sosial dan ekonomi kepada makanan yang mencukupi, selamat dan berkhasiat. Selain itu, makanan tersebut mestilah memenuhi keperluan pemakanan seharian untuk membolehkan individu tersebut menjalani gaya hidup yang aktif dan sihat. Ketiadaan sekuriti makanan bermaksud gangguan kepada pengambilan makanan atau pola makan kerana kekurangan wang dan sumber lain.

Menurut The State of Food Security and Nutrition in the World, yang diterbitkan oleh agensi Food and Agriculture Organization (FOA) dan World Health Organization (WHO), kira-kira 2 bilion orang di dunia mengalami masalah sekuriti makanan yang sederhana atau teruk. Kekurangan akses makanan yang berkhasiat dan mencukupi secara kerap meletakkan mereka berisiko kekurangan zat makanan dan kesihatan yang lemah. Majoriti individu yang berhadapan dengan masalah ini adalah mereka yang tinggal dalam negara berpendapatan rendah, dan lebih ramai wanita berbanding lelaki. Impak masalah sekuriti makanan amat besar, dan ini termasuklah ketidakstabilan politik, ketidakseimbangan ekonomi, dan kemiskinan yang berterusan (FAO et al, 2019).

Salah sebuah negara yang turut berhadapan dengan isu sekuriti makanan adalah New Zealand, yakni salah sebuah negara maju yang mempunyai pendapatan per kapita yang tinggi. New Zealand merupakan sebuah negara yang berkependudukan sekitar 5,002,100 juta (Stats NZ, 18 Mei 2020). Sebagai negara maju, New Zealand menduduki tahap tinggi dalam perbandingan prestasi nasional di peringkat antarabangsa, seperti kualiti kehidupan, pendidikan, perlindungan kebebasan sivil, ketelusan pemerintah, dan kebebasan ekonomi. Jumlah eksport makanan New Zealand boleh memberi makan seramai 20 juta orang yakni empat kali ganda penduduknya.

Walaupun sedemikian, laporan FOA et al (2019) menyatakan bahawa 14.0\% populasi New Zealand berhadapan dengan isu sekuriti makanan pada tahun 2018, jauh lebih tinggi daripada negara-negara maju di Eropah dan Amerika Utara yang mempunyai purata kadar 8.4\% (FAO et al, 2019). Apabila pandemik Covid-19 menyelinap masuk ke New Zealand dan impak pandemik semakin meruncing, situasi menjadi semakin buruk apabila dianggarkan bahawa jumlah penduduk New Zealand yang berhadapan dengan isu sekuriti makanan akibat pandemik Covid-19 adalah sebanyak 1 juta orang yakni 20\% daripada penduduknya pada tahun 2020 jika dibandingkan dengan 10\% pada tahun 2019 (FAO et al, 2019).

Mengapakah keadaan ini berlaku? Jika New Zealand merupakan antara pengeksport utama makanan, mengapakah isu sekuriti makanan berlaku di kalangan penduduknya sebelum dan semasa pandemik Covid-19? Siapakah golongan yang paling terjejas? Dengan menggunakan pendekatan analisis sejarah yang meneliti sebab-musabab berdasarkan sumber primer dan sekunder, kajian ini bertujuan untuk 
DOI: https://doi.org/10.47405/mjssh.v6i6.832

menelusuri dinamika masalah sekuriti makanan yang berlaku di kalangan rakyat sebelum dan semasa pandemik Covid-19. Berlandaskan kepada kajian kes ke atas negara New Zealand, kajian ini cuba merungkaikan isu sekuriti makanan yang dialami oleh rakyat New Zealand dalam tempoh dua dekad kebelakangan ini dan sejauh mana pandemik Covid-19 telah memberi impak kepada rakyat bersabit dengan isu sekuriti makanan.

\section{Sekuriti Makanan dan Pandemik: Suatu Latar Belakang Umum}

Secara umumnya individu akan mempunyai 'sekuriti makanan' apabila pada setiap masa individu ini boleh memperoleh makanan yang mencukupi untuk meneruskan hidup yang sihat dan aktif. Definisi sekuriti makanan yang diperkenalkan di Sidang Kemuncak Makanan Sedunia 1996 telah dimurnikan oleh Food and Agriculture Organization (FOA) pada tahun 2002. Dalam glosari laporan tahunan FAO, sekuriti makanan dijelaskan sebagai "a situation that exists when all people, at all times, have physical, social and economic access to sufficient, safe and nutritious food that meets their dietary needs and food preferences for an active and healthy life" (FAO, 2002). Definisi ini memperkenalkan elemen baru: aspek sosial kepada akses makanan. Aspek ini merujuk kepada keperluan untuk mempertimbangkan kebolehcapaian (aksesibiliti) makanan mengikut faktor seperti etnik, agama, dan hubungan politik. Faktor-faktor ini mempengaruhi kuantiti makanan yang dimakan, pemakanan, kepelbagaian dan pengambilan makanan yang kaya dengan nutrien.

Dimensi sekuriti makanan yang diterima secara meluas termasuklah, (1) ketersediaan makanan, iaitu jumlah makanan yang tersedia secara konsisten; (2) akses makanan, atau sumber yang mencukupi untuk mendapatkan makanan yang sesuai untuk diet berkhasiat; (3) penggunaan makanan, melalui diet yang mencukupi, air bersih, sanitasi dan penjagaan kesihatan untuk mencapai kesejahteraan di mana semua keperluan fisiologi dipenuhi, dan (4) kestabilan makanan, yang merujuk kepada kestabilan kepada ketersediaan, akses dan penggunaan makanan, dan dicapai apabila bekalan produk makanan yang reliable tersedia untuk semua orang pada setiap saat (FAO, Jun 2006). Sejauh mana setiap dimensi ini menyokong golongan rentan adalah berbeza-beza di seluruh dunia. Selain itu, tahap dan manifestasi masalah sekuriti makanan adalah dalam pelbagai bentuk dengan latar belakang ekonomi yang berbeza.

Dalam konteks "food insecurity" pula, ia merujuk kepada keadaan di mana individu tidak mempunyai akses yang mencukupi ke atas sumber-sumber yang diperlukan untuk diet yang berkhasiat (FAO, 2015). Ia boleh berlaku apabila sekuriti makanan terhad atau tidak menentu. Masalah sekuriti makanan adalah kronik dalam situasi akses jangka panjang yang tidak mencukupi kepada jumlah makanan yang bersesuaian, yang dikaitkan dengan kemiskinan yang berkekalan dan digabungkan dengan kekurangan mekanisme untuk menangani kerana keadaan yang kompleks atau kekurangan aset dan akses yang tidak mencukupi ke atas sumber daya produktif atau kewangan (Thomson dan Metz 1996). Masalah sekuriti makanan kronik mempunyai beberapa manifestasi, termasuk kekurangan akses makanan dan stok makanan, catuan makanan yang tidak mencukupi sepanjang tahun, kekurangan zat makanan pada kanak-kanak di bawah usia lima tahun, pembelian makanan dalam jumlah kecil dan hutang isi rumah yang belum dijelaskan (Sassi, 2018: 12). Masalah sekuriti makanan sementara pula berlaku apabila ketidakadaan akses yang mencukupi ke atas makanan bersifat sementara atau berlaku dalam jangka pendek. Ia boleh bersifat sementara (apabila gegaran yang tidak dapat diramalkan secara tiba-tiba mempengaruhi hak isi rumah) atau kitaran/bermusim (apabila terdapat pola berkala ke atas akses makanan yang tidak mencukupi) (Sassi, 2018; FIVIMS 2003).

Jika dilihat makanan terangkum dalam ekosistem global yang luas di mana aspek geopolitik, ekonomi, politik dan persekitaran mempunyai pertalian yang intim dengan masalah sekuriti makanan (Kaiser et al., 2015). Isu sekuriti makanan pula mempunyai kaitan rapat dengan aspek kesihatan, pembangunan ekonomi yang mapan, persekitaran dan perdagangan (WHO, 2015). Menurut beberapa orang sarjana, ia dikaitkan dengan kemiskinan dan mempengaruhi golongan rentan seperti kanak-kanak, orang tua, gelandangan, etnik minoriti dan ketua isi rumah wanita (Warr, 2014; Martinez dan Kawam, 2014; Franklin et al., 2012). Isu sekuriti makanan dalam kalangan golongan ini mempunyai implikasi serius terhadap kesejahteraan, seperti peningkatan kerentanan terhadap penyakit kronik, imuniti yang lemah, 
implikasi negatif terhadap kesihatan mental dan juga kematian (Yousafzai et al, 2013; McLaughlin et al., 2012, FAO, 2010). Ketidakupayaan untuk mendapatkan makanan yang mencukupi boleh menyebabkan kekurangan zat makanan, yang seterusnya dapat memberi kesan negatif terhadap prestasi sekolah dan kemampuan bekerja.

Secara umumnya pandemik boleh didefinisikan berdasarkan beberapa ciri. Ia merujuk kapada pergerakan penyakit, yakni wabak penyakit berjangkit yang merebak dalam skala besar, menjangkau kawasan geografikal yang luas, misalnya merentasi benua atau di seluruh dunia, dan memberi kesan ke atas sebahagian besar populasi (Last, 1988). Sesetengah pandemik juga dicirikan dengan kadar keberjangkitan (infectiousness) yang tinggi dan boleh menular (contagious) dengan mudah dari seorang individu kepada individu lain, seperti influenza. Kekebalan (immunity) populasi pula amat minimum terhadap penyakit tersebut. Pandemik juga dikatakan mempunyai ciri novelti atau menggambarkan penyakit yang baru, atau setidak-tidaknya terkait dengan varian baru organisma yang ada - misalnya, perubahan antigenik yang terjadi pada virus influenza (Morens et al, 2009). Sepanjang perjalanan sejarah, pandemik telah memberi impak buruk terhadap manusia, kadang-kadang mengubah perjalanan sejarah dan menandakan berakhirnya seluruh peradaban.

Sejak abad ke-20, terdapat beberapa wabak penyakit yang dilabelkan sebagai pandemik kerana jaringan penyebaran yang meluas dan merentasi kawasan geografi yang ekstensif. Paling utama adalah "the mother of all pandemics" iaitu Spanish Flu (1918-1919) dengan 500 juta orang telah menjadi mangsa selesema influenza ini. Gen dari virus 1918 ini telah ditemui dalam hampir semua pandemik influenza yang wujud selepas itu (Taubenberger, 2006). Hampir 40 tahun selepas Spanish Flu, yakni pada tahun 1957-1958, dunia gempar dengan pandemik selesema Asia (H2N2) yang bermula di China, dan tersebar merentasi benua sehingga Amerika Syarikat dan meragut lebih dari 1 juta nyawa. Virus yang menyebabkan wabak ini adalah gabungan virus selesema burung. Pada tahun 1968, pandemik H3N2 muncul di Hong Kong dan merebak sehingga ke Amerika Syarikat dan Eropah. Pandemik pertama abad ke-21 muncul pada musim bunga tahun 2009 apabila virus influenza A H1N1 yang baru (dari khinzir) telah dikesan di Mexico dan Amerika Syarikat dan merebak ke seluruh dunia. Dalam satu tahun, virus itu telah membunuh antara 151,700 dan 575,400 orang (Relman et al, 2010). Kesemua pandemik ini telah meninggalkan kesan yang mendalam ke atas kehidupan manusia.

Pandemik Covid-19 yang wujud pada hujung tahun 2019 merupakan satu lagi episod pandemik yang telah menyebabkan kelumpuhan melibatkan hampir semua aktiviti sosial manusia di seluruh dunia. Penyakit Coronavirus 2019 (COVID-19) didefinisikan sebagai penyakit yang disebabkan oleh koronavirus baru yang kini disebut sebagai sindrom pernafasan akut teruk koronavirus 2 (SARS-CoV2; sebelumnya disebut 2019-nCoV), pertama kali dikesan di Wuhan, Wilayah Hubei, China pada penghujung tahun 2019 (Cennimo, 2021). Ia telah merebak dengan pantas ke seluruh dunia, terutamanya ke negara-negara seperti Korea Selatan, Itali dan Iran. Pertubuhan Kesihatan Sedunia (WHO) telah mengisytiharkan Covid-19 sebagai pandemik global pada 11 Mac 2020 setelah penilaian dibuat ke atas penularan wabak tersebut yang mempunyai keupayaan untuk merebak melalui populasi manusia dan merentasi kawasan luas sehingga melepasi sempadan negara dan benua malah ke seluruh dunia. Setakat 5 Mei 2021, WHO melaporkan sejumlah 3,221,052 juta kes kematian direkodkan dengan jumlah kes kumulatif Coronavirus di seluruh dunia mencecah 153,954,491 (WHO, 2021). Negara-negara seperti India, Amerika Syarikat, Brazil, Turki dan Perancis merupakan negara yang mencatatkan kadar kes baharu tertinggi dengan India melaporkan lebih daripada 300,000 kes baru seharian dalam masa dua minggu terakhir ini - satu angka yang dianggap konservatif oleh golongan pakar (Pal, 2021). Jumlah kes secara keseluruhan mengikut WHO dan pembekal data yang lain telah memberikan gambaran betapa pandemik Covid-19 bakal menjadi krisis kesihatan terburuk yang pernah berlaku dalam sejarah peradaban manusia selepas pandemik Spanish Flu pada tahun 1918 dahulu.

Menurut Pan American Health Organization (PAHO), kesan kesihatan global dari pandemik influenza boleh mempengaruhi tenaga kerja, sistem pengangkutan, dan rantaian bekalan. Kesan virus di kawasan lain di dunia boleh menyebabkan masyarakat di tempat lain mengalami krisis makanan sebelum virus influenza tiba di tempat mereka. Antara indikator penting bagaimana pandemik boleh menyebabkan masalah sekuriti makanan adalah bila mana industri yang bergantung kepada import dan eksport 
sedang bergelut, bekalan makanan sukar diperoleh secara lokal dan kegiatan ekonomi terganggu (PAHO, tiada tarikh).

Sebelum wujudnya virus COVID-19, isu sekuriti makanan sudah melanda di sesetengah tempat dengan kelaparan kronik dan akut sudah sedia meningkat disebabkan oleh pelbagai faktor termasuk konflik, keadaan sosio-ekonomi, malapetaka semula jadi, perubahan iklim dan serangga perosak. FAO menganggarkan bahawa jumlah kekurangan zat makanan (termasuk mereka yang mengalami kelaparan kronik dan akut) meningkat dari 624 juta orang pada tahun 2014 kepada 688 juta pada tahun 2019 (The World Bank, 2021). Pandemik Covid-19 telah memburukkan lagi keadaan ini bila impak COVID-19 telah menyebabkan peningkatan yang teruk dan meluas dalam aspek sekuriti makanan global. Gangguan ekonomi dan sosial yang disebabkan oleh pandemik amat dahsyat bila mana puluhan juta orang berisiko terjerumus dalam kemiskinan yang melampau, sementara jumlah orang yang kurang makan juga meningkat secara drastik. Krisis kesihatan global yang berlaku telah mempengaruhi sistem makanan dan mengancam akses kepada makanan melalui pelbagai dinamika. Bukan sahaja gangguan besar terhadap rantaian bekalan makanan akibat "lockdown" tetapi juga berlaku perkembangan ekonomi global yang amat perlahan (The World Bank, 2021). Krisis ini telah membawa kepada kenaikan harga runcit bagi sesetengah barangan dan digabungkan lagi dengan penurunan pendapatan menyebabkan semakin banyak isi rumah tidak dapat menjangkau makanan apabila ada yang terpaksa mengurangkan kuantiti dan kualiti penggunaan makanan mereka. Ini telah memperkecilkan objektif di mana setiap individu ada hak untuk memperoleh makanan dan menjejaskan usaha yang digariskan pada tahun 2015 untuk mencapai "Sustainable Development Goal (SDG) 2: "Zero hunger" menjelang tahun 2030. Menurut WHO, pandemik Covid-19 akan terus membawa impak buruk (Ghebreyesus, 2020) kerana virus ini akan terus berlegar di kalangan masyarakat sekurang-kurangnya satu atau dua tahun lagi (Scudellari, 2020).

\section{Isu Sekuriti Makanan di New Zealand sebelum Penularan Pandemik Covid-19}

Reputasi New Zealand sebagai negara maju dengan sistem pertanian yang kukuh menyebabkan ramai orang menganggap bahawa negara ini tidak akan terkesan dengan isu sekuriti makanan. Sebagai sebuah negara pengeluar makanan, New Zealand sememangnya tidak berhadapan dengan masalah kekurangan makanan dalam negara kerana New Zealand merupakan antara negara di dunia yang boleh berdikari, dan pada masa yang sama menyumbang kepada keperluan pemakanan global. Adalah didapati bahawa $45 \%$ daripada tanah subur New Zealand dikhaskan untuk pengeluaran makanan dengan para petani mengeksport makanan yang mencukupi untuk 20 juta penduduk, yakni empat kali ganda penduduk New Zealand yang hanya sekitar 5 juta (Rush, 2019). Antara produk yang mendominasi eksport New Zealand adalah tenusu, daging lembu dan kambing biri-biri, buah kiwi, epal, bawang dan wain. Jumlah import makanan pula boleh memberi makan seramai 10 juta orang, yakni dua kali ganda penduduk New Zealand (Rush, 2019).

Pada hakikatnya, isu sekuriti makanan adalah suatu isu global yang juga memberi impak kepada New Zealand. Ini diakui sendiri oleh Ketua Pengarah Kesihatan, Dr. Ashley Bloomfield, pada tahun 2019, "Food insecurity is an issue that no New Zealand family should have to worry about. Unfortunately this is not currently the case in Aotearoa/New Zealand" (Ministry of Health, 2019:III). Masalah yang timbul sebenarnya adalah aksesibiliti kepada makanan tersebut. Seseorang akan dianggap sebagai "food insecure" jika terpaksa menggunakan geran keperluan khas atau bank makanan; membeli barangan atau makanan yang lebih murah untuk membolehkan mereka membeli barangan lain; dan kerap kali mengabaikan buah-buahan dan sayuran segar (Carter et al, 2010).

Pada dekad pertama abad ke-21, suatu survei telah dibuat ke atas masalah sekuriti makanan di kalangan penduduk New Zealand. Angka survei tahun 2008/09 menyatakan bahawa 7.3\% rakyat mengalami masalah sekuriti yang serius sementara 33\% pula sederhana (Graham, 2019). Lebih kurang 20\% isirumah New Zealand adalah disebabkan oleh kekurangan wang untuk membeli makanan, yang diperburukkan lagi dengan indeks harga makanan yang terus meningkat. Selain itu, lokasi kediaman yang jauh, bilangan isi rumah yang tinggi dan etnisiti turut mempengaruhi masalah sekuriti makanan di kalangan rakyat (Bowers et al, 2009; Rush dan Rusk, 2009; Carter et al, 2010) . 
Dekad kedua abad ke-21 juga menunjukkan dapatan yang hampir serupa. Dalam tempoh lima tahun (2014-2019), kos harga makanan telah meningkat sebanyak 4\% tetapi buah dan sayur-sayuran telah mengatasi ini, dengan kenaikan kos sebanyak 9\% (Rush, 2019). Ini amat memberi kesan ke atas rakyat. Tinjauan yang dibuat oleh Kementerian Kesihatan New Zealand pada 2015/2016 melaporkan sekurang-kurang satu daripada lima kanak-kanak yang berumur antara 2 hingga 14 tahun di New Zealand (19\%) tinggal di dalam isi rumah yang mengalami isu sekuriti makanan tahap sederhana ke tahap teruk (Ministry of Health, 2019). Kanak-kanak yang mengalami isu sekuriti makanan ini biasanya tinggal di kawasan kejiranan yang miskin; mempunyai pendapatan isi rumah yang rendah; mendapat bantuan kerajaan; tinggal di rumah sewa; terdiri dari etnik Pasifik atau Maori; dan tinggal bersama dua atau lebih kanak-kanak dalam rumah.

Kanak-kanak ini akan terjejas nutrisi dan pemakanan mereka kerana mereka tidak akan mendapat nutrisi yang diperlukan untuk tumbesaran yang sihat (Fram et al, 2015). Berbanding dengan kanakkanak yang tidak mempunyai isu sekuriti makanan, kanak-kanak yang terjejas pemakanannya akan kurang mengambil buah-buahan dan sayur-sayuran, tidak akan mengambil sarapan sebelum ke sekolah, dan akan memakan lebih banyak makanan segera dan minuman bersoda (Child Poverty Action Group, Ogos 2019:3-4). Ini akan menimbulkan masalah obesiti (Utter et al 2012), status kesihatan yang lebih buruk dan kadar perkembangan dan tingkah laku yang lebih bermasalah yang turut akan mempengaruhi prestasi sekolah (Whitaker et al, 2006).

Dari segi sejarah, peribumi Maori telah kehilangan hampir 95\% tanah dan sumber mereka berikutan penjajahan Eropah pasca-1840 (Beavis et al, 2019) yang seterusnya menjadikan kaum pribumi Maori hidup secara terpencil dan menjadi golongan yang paling teruk terjejas apabila berlakunya epidemik (cacar air pada tahun 1913) atau pandemik (Spanish Flu 1918 hingga 1919). Kekurangan tanah untuk menampung pertambahan penduduk menyumbang kepada migrasi sejumlah besar Maori ke bandar, dan penyertaan dalam ekonomi yang berasaskan pembayaran upah (Poata-Smith, 2013). Namun, ini membuat Maori rentan terhadap penstrukturan semula ekonomi yang bermula pada tahun 1984 dan berlanjutan hingga tahun 1990-an, mengakibatkan kehilangan pekerjaan yang besar di daerah di mana Maori adalah dominan. Kadar pengangguran Maori telah semakin pulih sejak kemuncaknya $(27.3 \%)$ pada tahun 1992, namun masih terdapat perbezaan pekerjaan yang luas di New Zealand mengikut etnik dan ini mempengaruhi pendapatan isi rumah (Beavis et al, 2019).

Sebelum krisis Covid-19 berlaku, dua daripada tiga whānau (keluarga besar) dari isirumah Maori sudah berhadapan dengan isu aksesibiliti kepada makanan berkhasiat. Faktor utama ini berlaku adalah kemiskinan, disokong lagi dengan penyebab lain seperti isu pengangkutan atau tinggal terlalu jauh dari sumber makanan. Pendapatan yang rendah atau terhad menyebabkan kemampuan berbelanja juga menjadi terhad dalam kalangan masyarakat pribumi Maori. Sebilangan besar whānau tidak memperoleh pendapatan yang mencukupi untuk membeli makanan sihat yang sepatutnya walaupun pada tahun 2009 FOA telah mengenal pasti akses kepada makanan sebagai hak asasi manusia, khususnya untuk masyarakat peribumi (Kira, 2020).

Bagi kumpulan etnik Pasifik pula (yang terdiri daripada Samoan, Cook Islands Maori, Tongan, Niuean, Fijian, Tokelauan dan Tuvakuan), isu sekuriti makanan juga amat mendalam. Pada tahun 1997, 60\% daripada isirumah etnik Pasifik menyatakan mereka mampu untuk makan dengan baik berbanding dengan $90 \%$ penduduk New Zealand berketurunan Eropah dan lain-lain (NZEO). Lima tahun kemudian, yakni pada tahun 2002, hanya 46.6\% isirumah etnik Pasifik mampu makan dengan baik berbanding dengan $86.1 \%$ isirumah NZEO. Kedua-dua survei yang dibuat (1997 dan 2002) membuktikan bahawa lebih 50\% penduduk Pasifik dewasa dan kanak-kanak terbeban kerana isu sekuriti makanan berbanding dengan etnik lain. Di antara kedua-dua tahun itu juga menandakan berlakunya penurunan dalam sekuriti makanan bagi isirumah etnik Pasifik (dan etnik Maori serta etnik NZEO). Masalah sekuriti makanan ini merangkumi aspek tidak dapat makan dengan baik, kehabisan makanan, kurang makan kerana tiada duit dan ini turut mempengaruhi jenis makanan yang dimakan, bergantung kepada pihak lain untuk mendapatkan makanan, serta menggunakan geran makanan atau bank makanan (Rush \& Rusk, 2009). 
Bentuk tingkah laku dan akses komuniti Pasifik terhadap makanan banyak dipengaruhi oleh lokasi geografi, perbezaan etnik, bahasa, saiz keluarga, budaya serta pandangan dunia, agama Kristian yang kuat dan ikatan dengan gereja, status sosioekonomi (termasuk status kesihatan, pekerjaan, tempat kerja dan syif kerja), tempoh masa di New Zealand, dan akhir sekali, bekalan, akses dan keperluan. Dalam konteks gereja misalnya, gereja mempunyai tempat yang khas dalam komuniti Pasifik dan memainkan peranan utama dalam membekalkan informasi dan perkhidmatan. Dalam kajian yang pernah dilaporkan pada tahun 2020, 92\% daripada ibu-ibu melaporkan afliasi mereka dengan institusi keagamaan dan 65\% mempunyai komitmen tradisi kepada keluarga atau gereja. Dua pertiga daripada mereka menegaskan bahawa memberi hadiah/komitmen kepada keluarga atau gereja telah menyebabkan situasi kewangan mereka semakin buruk. Tekanan rakan sekerja (peer pressure) juga digunakan untuk mendorong keluarga untuk "menggadaikan rumah mereka, berlapar atau menjadi muflis" untuk membuat pembayaran kepada gereja dan keluarga di pulau asal mereka (Rush \& Rusk, 2009).

Terdapat pendapat yang menyatakan isu sekuriti makanan dan kemiskinan yang dihadapi oleh rakyat New Zealand pada abad ke-21 ini tidak ada beza dengan kehidupan rakyat yang tinggal di kawasan "slums" di London semasa era pentadbiran Ratu Victoria pada awal abad ke-20 (Graham, 2019: 3). Ini dapat dikesan dari jenis diet yang diambil oleh rakyat pada kedua-dua era. Reeves (1913) dalam kajiannya ke atas isu kemiskinan dan kematian bayi di kawasan Lambeth, selatan London, menyatakan diet yang dipilih oleh rakyat yang menghadapi masalah sekuriti makanan adalah murah dan mengenyangkan. Mereka tiada pilihan kerana yang perlu diambil kira adalah wang. Sementara itu, menurut penduduk New Zealand yang ditemu bual di wilayah Hamilton dan Greater Waikato pada abad ke-21 pula, dalam berhadapan dengan cabaran kemiskinan dan masalah sekuriti makanan, mereka mengutamakan makanan ruji yang memerlukan cara penyediaan makanan yang paling mudah, kos penyimpanan makanan yang minima, tidak mudah rosak, mengenyangkan dan memberi kepuasan. Ini termasuklah mee segera "2 minit" dan makanan bajet seperti roti, pasta, nasi, telur, susu dan makanan dalam tin (Graham, 2019). Dengan bantuan NZD25 untuk makanan seminggu, rakyat / ibu bapa bersikap pragmatik dan membeli apa yang penting sahaja. Menjadi perkara biasa bagi mereka untuk makan makanan tidak berkualiti misalnya makanan yang lepas tarikh, buruk atau tidak enak sebagai makanan harian kerana ia penting demi kelangsungan hidup mereka (Graham et al, 2018).

Impak ketiadaan sekuriti makanan ini telah menjejaskan kehidupan rakyat. Bukan sahaja mereka tidak mendapat nutrisi makanan yang diperlukan oleh seisi keluarga, ia turut memberi kesan ke atas hubungan kekeluargaan menyebabkan ibu bapa dan anak-anak dalam keadaan tertekan dan cemas. Ada yang berhadapan dengan isu gangguan pemakanan (eating disorder). Kadang kala ketegangan yang berlaku akan menimbulkan pergaduhan dan menjejaskan hubungan antara anak dan ibu bapa. Tekanan yang dihadapi kerana perlu "makan apa yang ada sahaja" turut meningkatkan bebanan emosi dan mental ibu bapa kerana tiada sumber untuk menyediakan makanan yang mencukupi. Dalam kebanyakan kes, ibu bapa akan berkorban untuk memastikan anak-anak mereka mempunyai makanan. Terdapat juga kanak-kanak yang prihatin dengan cabaran yang dihadapi oleh ibu bapa mereka dan melakukan yang terbaik untuk membantu. Ada yang membawa pulang sisa makanan dari sekolah atau acara komuniti untuk seisi keluarga. Pilihan lain termasuklah membongkar tong sampah, dan mencari kerja sambilan dan upah yang diterima akan digunakan untuk membeli makanan (Graham, 2019).

Tatkala berhadapan dengan isu sekuriti makanan, ramai yang akan menggunakan geran makanan atau bank makanan yang disediakan oleh badan kerajaan atau badan bukan kerajaan. Pada Jun 2018, sebanyak 88,000 keluarga yang mempunyai kanak-kanak mendapat bantuan geran khas yang dikaitkan dengan keperluan makanan (Perry, 2018). Sementara itu, sebuah organisasi bukan kerajaan iaitu Salvation Army mendakwa mereka telah edarkan 56,500 bungkusan makanan kepada 29,500 keluarga pada tahun 2016. Jumlah ini meningkat sebanyak 12\% di antara tahun 2016 dan 2017. Penggunaan bank makanan atau geran dikaitkan dengan banyak faktor selain keperluan, termasuk ketersediaan di peringkat lokal dan stigma. Ini bererti bahawa jumlah isi rumah yang mendapat manfaat daripada penggunaan bank makanan atau geran untuk memenuhi keperluan mereka adalah lebih tinggi (Ministry of Health, 2019). Jumlah ini bertambah berlipat kali ganda apabila pandemik Covid-19 berlaku pada penghujung 2019. 
DOI: https://doi.org/10.47405/mjssh.v6i6.832

\section{Dasar Kerajaan New Zealand terhadap Pandemik Covid-19: “Go Hard, Go Early" , “Unite Against Covid-19”}

Pada tahun 2019, New Zealand menduduki tempat ke-35 di dunia dalam indeks kesediaan menghadapi pandemik berbanding dengan jirannya Australia (kedudukan ke-4), dan di belakang Indonesia dan Afrika Selatan (Mc Lean, 16 Februari 2020; Stockman, 4 Januari 2021). Sistem kesihatan awam yang bergelumang dengan hutang dan tiada kawalan pusat yang kukuh dipimpin oleh Kementerian Kesihatan yang lemah. Ini dibuktikan dengan keterbatasan dan tindak balas Kementerian Kesihatan yang tidak bersemangat terhadap wabak campak yang berlaku pada tahun 2019. Pada dasarnya, New Zealand tidak bersedia untuk COVID-19 (Stockman, 4 Januari 2021).

Kes pertama Covid-19 dilaporkan berlaku di New Zealand pada 28 Februari 2020. Ini merupakan jangkitan dalam komuniti melibatkan seorang rakyat New Zealand berusia 60 tahun yang baru kembali dari Tehran, Iran menggunakan Emirates Airline melalui Bali, Indonesia. New Zealand mengesahkan kes kedua pada 4 Mac 2020, seorang wanita berusia 30-an yang baru kembali dari utara Itali. Jumlah kes terus mencatatkan peningkatan yang ketara sepanjang Mac 2020, sejumlah 58 kes baharu dicatatkan pada 31 Mac menjadikan jumlah kes keseluruhan Covid-19 di New Zealand mencecah 647 kes seperti yang dilaporkan oleh Dr Ashley Bloomfield selaku Pengarah Kesihatan New Zealand dalam satu sidang media harian yang diadakan bersama dengan Sarah Stuart-Black yang juga merupakan Pengarah Pengurusan Pertahanan Awam dan Kecemasan (Stuff, 31 Mac 2020).

Menurut Healy dan Malhotra (2009), melabur demi pencegahan adalah jauh lebih cekap dan menjimatkan kos daripada bertindak balas terhadap krisis (Healy dan Malhotra, 2009: 388). Inilah yang telah dilakukan oleh kerajaan New Zealand pada peringkat awal pandemik Covid-19 mula menyelinap masuk ke negara tersebut. Langkah awal kerajaan pimpinan Ardern adalah menggerakkan Pusat Penyelarasan Kesihatan Nasional (National Health Coordination Centre) kira-kira sebulan sebelum kes pertama Covid-19 dilaporkan di New Zealand. PPKN ini berfungsi untuk memantau penularan wabak serta kemudiannya mengeluarkan amaran berkaitan penyakit berjangkit kepada masyarakat untuk mempersiapkan rakyat New Zealand mengambil langkah berjaga-jaga dalam berhadapan sebarang kemungkinan krisis kesihatan terburuk bakal berlaku. Walaupun kedudukan geografi New Zealand agak terasing, kerajaan sedar akan ancaman dan bahaya Covid-19 kerana jumlah tinggi pelancong dan pelajar yang tiba dalam negara tersebut setiap musim panas, terutama dari Eropah dan tanah besar China. Mereka menjangkakan penyakit tersebut akan menyebar secara meluas, melumpuhkan sistem kesihatan, dan akan membebani penduduk Maori dan Pasifik yang lain (Baker, Wilson \& Anglemyer, 2020: e56(1)).

Oleh kerana itu, kerajaan New Zealand mula mengimplementasikan agenda menangani pandemik secara bersungguh-sungguh pada bulan Februari, termasuk menyediakan hospital untuk menerima pesakit yang ramai. Polisi kawalan sempadan juga dikuatkuasakan untuk menghalang penularan penyakit Covid-19. Rakyat New Zealand yang baru kembali dari China diwajibkan untuk menjalani kuarantin selama 14-hari di fasiliti tentera yang disediakan. Ardern telah mengarahkan penutupan semua sempadan negara berkuatkuasa serta merta pada 3 Februari 2020. Tindakan kerajaan ini menunjukkan betapa seriusnya kerajaan mendepani isu pandemik Covid-19 walaupun belum ada kes dilaporkan di negara tersebut pada waktu itu.

Namun demikian, menjelang pertengahan Mac 2020, transmisi dalam kalangan komuniti semakin meningkat di New Zealand. Rantaian transmisi tersebar di seluruh negara, dengan kes tertinggi di kawasan pelancongan yang popular dan acara perkahwinan di mana rantaian transmisi merangkumi pelbagai kumpulan umur (Robert, 2020). Tidak seperti Taiwan, Singapura dan Korea Selatan, New Zealand tidak terkesan dengan SARS dan MERS, dan oleh itu, tiada pengalaman menghadapi pandemik seperti mana yang dilalui oleh negara-negara jirannya di Asia. Unit kesihatan awam bukan sahaja tidak mempunyai kit ujian yang mencukupi malahan ia juga tidak mempunyai kapasiti untuk melaksanakan pengesanan kontak rapat untuk menghalang transmisi yang semakin pantas (Stockman, 4 Januari 2021). Amat jelas bahawa Covid-19 akan menjejaskan sistem kesihatan dengan amat mendalam sekali dan berkemungkinan akan menyebabkan kematian yang tinggi. 
Justeru itu, New Zealand telah mengambil tindakan drastik. Semua program sosial masyarakat tidak dibenarkan dan larangan tersebut berkuatkuasa pada 16 Mac 2020. Pengembara yang kembali ke New Zealand diwajibkan untuk menjalani kuarantin kendiri selama 14 hari. Pada 19 Mac 2020 para pesara bidang kesihatan diminta untuk melaporkan diri bagi membantu kerajaan memberikan khidmat di hospital dan juga pusat kesihatan (Rice, 2020). Pada 21 Mac, Ardern mengumumkan sistem respon pandemik empat tahap yang menerangkan tindak balas serta peraturan berbeza yang perlu dipatuhi oleh orang ramai dan perniagaan untuk mengurangkan perebakan Covid-19. Peraturan Tahap 1 adalah yang paling longgar sementara Tahap 4 paling ketat. Pada 25 Mac 2020, New Zealand masuk ke Tahap 4 dengan pengisytiharan darurat dan "lockdown" dikuatkuasakan di seluruh negara pada jam 11.59 malam selama lebih kurang empat minggu setengah (RNZ, Februari 2021).

Sistem respons Tahap 4 merupakan antara yang paling ketat di dunia dan hanya membenarkan kumpulan "essential services" atau "perkhidmatan penting" saja untuk beroperasi. Semua rakyat New Zealand diarahkan untuk tinggal di rumah kecuali mereka adalah pekerja "essential". Bidang perkhidmatan penting ini merujuk kepada pelbagai aktiviti tetapi dalam konteks penyediaan atau pembekalan makanan ini termasuklah; bekalan, penghantaran, pengedaran, dan penjualan makanan, minuman dan barangan lain yang penting untuk menjaga kesejahteraan rakyat, pengeluaran dan pemprosesan makanan, dan penyediaan perkhidmatan kebajikan dan sosial. Walaupun perkhidmatan penting ini termasuk pengeluaran dan pengedaran makanan, terdapat sejumlah perkhidmatan makanan yang dikecualikan dan perlu ditutup misalnya penjual daging, kedai roti, restoran, kafe, bar, dan peniaga makanan skala kecil yang lain (New Zealand Government. Essential Business, 2020).

Dari segi sejarah, pendekatan yang digunakan biasanya bermodelkan mitigasi dan berfokus untuk melambatkan kedatangan virus, diikuti dengan pelbagai langkah untuk meratakan lekukan kes dan kematian. Keputusan New Zealand untuk mengimplementasikan pendekatan penghapusan amat berbeza dengan perancangan menangani pandemik yang konvensional. Apabila lockdown menunjukkan hasil yang memberangsangkan Ardern mengabaikan strategi mitigasi yang sekadar "meratakan lekukan" dan beralih kepada strategi penghapusan sekali gus (Cousins, 2020; Baker, Wilson \& Anglemyer, 2020). Tujuh minggu kemudian lockdown ditamatkan, dan New Zealand kembali normal. Selepas 103 hari COVID-19 telah berjaya dihapuskan.

Kepantasan penilaian risiko yang dikaitkan dengan tindakan awal, tegas dan efisien kerajaan dipercayai amat kritikal dalam membantu Perdana Menteri Ardern mengawal penularan Covid-19 di New Zealand sehingga mendapat perhatian dan pujian masyarakat antarabangsa. Pemimpin kerajaan menyedari negaranya tidak bersedia, dan sistem kesihatan mereka tidak dapat menahan "serangan" Covid-19. Oleh sebab itu, kerajaan pimpinan Ardern menggunakan pendekatan "Go hard, and go early" dalam program intervensi yang dilakukan (Jamieson, 2020). Ardern juga telah menunjukkan ciri kepemimpinan yang berempati dan telah berkomunikasi secara efektif dengan menyampaikan mesejmesej utama kepada orang awam dan meletakkan agenda memerangi pandemik Covid-19 melalui kempen "Unite Against Covid-19" sebagai tanggungjawab dan kerjasama "Team of 5 Milion". Papan iklan dan suapan berita di media sosial dipenuhi dengan mesej-mesej kempen. Risalah juga diedarkan di setiap bandar, kota dan peti surat di negara ini. Setiap petang, Ardern dan Ketua Pengarah Kesihatan muncul di televisyen dan memberikan informasi terkini secara terperinci, dengan mengulangi maklumat penting berulang kali. Mesej penting seperti 'Stay Home - Save Lives' diterjemahkan ke dalam puluhan bahasa, dan disalurkan kepada komuniti melalui gereja, masjid, pemimpin masyarakat dan media sosial yang berpengaruh (Stockman, 2021).

Tinjauan pendapat umum yang secara konsistennya melebih $80 \%$ sokongan kepada polisi kerajaan (termasuk lockdown) mempamerkan keyakinan masyarakat awam yang tinggi terhadap kepimpinan Ardern sehingga mereka patuh kepada kaedah-kaedah kawalan pandemik yang bukan sahaja boleh membebankan mereka tetapi menafikan kebebasan sivil (Jamieson, 2020). Pada ketika wujudnya perubahan keadaan, kerajaan telah melakukan adaptasi dan pengubahsuaian untuk mengatasi kekurangan yang wujud dalam tindak balas kerajaan (Jamieson, 2020). Rasa kebanggaan nasional yang semakin meningkat juga wujud dalam kalangan rakyatnya. 
DOI: https://doi.org/10.47405/mjssh.v6i6.832

Walaupun New Zealand telah berjaya bebas daripada Covid-19 selama 103 hari pada Jun 2020, keadaan ini tidak kekal lama kerana penamatan lockdown dan pergerakan manusia sentiasa akan mendedahkan negara tersebut kepada risiko penularan semula wabak. Sejak Ogos 2020 sehingga kini (Mei, 2021), terdapat beberapa lockdown diisytiharkan di bandar Auckland dalam usaha mereka memerangi Covid-19. Sehingga 27 Mei 2021 jumlah kes yang masih aktif di New Zealand berada pada tahap dua angka iaitu 21 kes dengan jumlah kes keseluruhan 2670 dengan 26 kes kematian (Ministry of Health, 27 Mei 2021). Respon kerajaan New Zealand yang pantas dan efisyen mungkin akan dapat mengurangkan atau melenyapkan Covid-19 di negara tersebut dalam masa terdekat namun impak daripada pandemik ini akan terasa dalam satu jangka masa yang lama, terutamanya berkaitan dengan masalah sekuriti makanan.

\section{Masalah Sekuriti Makanan di New Zealand Akibat Pandemik Covid-19}

Pandemik global Covid-19 menimbulkan cabaran besar terhadap sekuriti makanan, terutamanya berkaitan akses makanan, ketersediaan, dan kestabilan. Kesan sepenuhnya pandemik kepada sistem makanan belum dapat dinilai. Apa yang jelas adalah pandemik mempunyai potensi secara signifikan untuk memburukkan ketidakseimbangan ekonomi yang sedia ada, dengan memberi impak kepada mereka yang sudah mengalami masalah sekuriti makanan. Respons pandemik yang ketat bermaksud dalam fasa Tahap 4 "Lockdown" kerajaan New Zealand secara efektifnya telah menghapuskan transmisi dalam komuniti Covid-19 selama 103 hari. Kemunculan semula kes baru Covid-19 pada bulan Ogos 2020 telah dibendung melalui respon Tahap 2 dan 3 mengikut kawasan. Tidak dinafikan kerajaan New Zealand berjaya dalam tindak balasnya melindungi kesihatan rakyat. Walau bagaimanapun, sekatan lockdown telah mengganggu sistem makanan dalam negara di semua peringkat, dari pengeluaran hingga pembuatan dan pemprosesan, pengedaran dan penggunaan makanan. Perkhidmatan sosial ditutup sementara atau terpaksa menyesuaikan diri dengan sekatan pandemik. Rakyat juga terpaksa mengubah amalan mereka dalam mendapatkan sumber makanan dan cara pemakanan.

Walaupun mengganggu proses pengeluaran, semasa penularan pandemik, New Zealand tidak berhadapan dengan isu ketersediaan bekalan makanan. Penolong Timbalan Ketua Pengarah Kementerian Industri Utama, Ruth Fairhall, berkata New Zealand telah lama menikmati lebihan makanan, berkat gabungan sumber semula jadi dan inovasi yang ada di negara tersebut. Justeru itu, negara berada dalam posisi yang baik untuk menghadapi gangguan pandemik terhadap perdagangan dan rantaian bekalan nasional dan antarabangsa. Kerajaan memberi jaminan bahawa industri makanan akan memastikan bekalan makanan yang berlarutan kepada warga New Zealand, dan akan terus mengeksport ke pasaran antarabangsa untuk sebahagian besar produk makanan negara (Mitchel, 2021). Masalah yang dihadapi oleh rakyat New Zealand dalam konteks sekuriti makanan adalah berfokuskan kepada aksesibiliti mereka kepada makanan apabila ramai yang tidak dapat makanan yang mencukupi akibat impak pandemik.

Auckland City Mission menganggarkan bahawa jumlah penduduk New Zealand yang berhadapan dengan isu sekuriti makanan semasa dan pasca pandemik Covid-19 adalah sebanyak 1 juta orang yakni $20 \%$ daripada penduduknya pada tahun 2020 jika dibandingkan dengan 10\% pada tahun 2019. Dengan keadaan penduduk kehilangan pekerjaan, pembelian panik di kedai dan faktor lain, pandemik Covid-19 telah mengancam isu sekuriti makanan secara lebih meluas di New Zealand (Grieser, September 2020). Indikator terbaik yang menunjukkan masalah sekuriti makanan di kalangan penduduk New Zealand adalah permintaan bantuan makanan kecemasan sejak permulaan lockdown Covid-19 telah meningkat dengan begitu ketara, lantas menunjukkan kesukaran bagi isirumah untuk memenuhi keperluan asas mereka (Neuwelt-Kearns, 2020). Bank makanan di seluruh negara menghadapi peningkatan besar dalam permintaan, dengan talian telefon menerima puluhan ribu panggilan kecemasan memerlukan bantuan, dan barisan di luar bank makanan Christchurch misalnya telah menyebabkan kesesakan lalu lintas (Mitchell, 31 Januari 2021). Pengumuman lockdown tahap 4 pada akhir Mac 2020 menyaksikan peningkatan tiga kali ganda bungkusan makanan yang dilaporkan oleh Christchurch City Missioner, sementara Wellington's City Missioner pula melaporkan permintaan bantuan makanan sebanyak 400\%. Salvation Army pula melaporkan edaran sebanyak 6000 bungkusan makanan seminggu semasa 
perintah kawalan pergerakan, yakni angka yang biasanya diedarkan dalam tempoh sebulan. Dalam tempoh tahun 2020, Salvation Army mengagihkan lebih daripada 113,000 bungkusan di seluruh negara, hampir dua kali ganda jumlah tahun 2019 (RNZ, 17 Februari 2021). Permintaan untuk geran makanan kecemasan daripada Kementerian Pembangunan Sosial (MSD) juga telah meningkat dalam tempoh tiga minggu selepas lockdown dikuatkuasakan dan pemberian geran khas untuk makanan telah meningkat dari 30,000 kepada 67,000 (Neuwelt-Kearns, 2020).

Menurut penyelidikan yang telah dibuat, peningkatan dalam permintaan bungkusan makanan dipengaruhi oleh kombinasi tiga faktor: penutupan atau ketiadaan operasi yang tidak berasaskan keuntungan, penutupan pembekal makanan kecil-kecilan, dan kehilangan pekerjaan/pendapatan lantas mengurangkan keupayaan untuk membeli makanan. Faktor pertama melibatkan beberapa pihak yang termasuk dalam sistem pengedaran makanan di New Zealand, terutamanya yang menjalankan operasi tanpa berasaskan keuntungan, terpaksa berhenti operasi dalam sekelip mata semasa sistem amaran Tahap 3-4 diimplementasikan. Ini kerana mereka tidak didaftarkan sebagai 'perkhidmatan penting', tidak dapat menyesuaikan diri dengan peningkatan keperluan kesihatan dan keselamatan atau logistik, atau sukarelawan mereka tidak dapat bekerja kerana faktor usia atau profil kesihatan mereka. Termasuk dalam golongan ini adalah perkhidmatan sosial yang merangkumi beberapa aspek penyediaan makanan (misalnya kumpulan belia, perkhidmatan dadah dan alkohol, makanan gereja, kelab sarapan sekolah), serta 'fellowship" tidak rasmi yang berlaku melalui keluarga dan masyarakat (Dombroski, et al, 2020).

Faktor kedua pula adalah penutupan pembekal makanan kecil-kecilan di mana transaksi berkisar kepada makanan berlaku. Ini termasuklah pasar tani, kafe, penjual daging, restoran, hotel, dan penyedia makanan segera. Penutupan perniagaan dan perkhidmatan pengagihan ini pada asasnya akan menyorong sebahagian besar transaksi makanan ke pasar raya. Perubahan ini mengganggu rantaian bekalan, yang mempengaruhi kedua-dua pengeluar dan pengguna. Seperti yang telah digambarkan oleh penduduk, semasa lockdown pasar sayur dan pasar buah tidak boleh beroperasi, dan ini telah melenyapkan 60\% daripada rantaian bekalan Auckland dalam satu malam sahaja. Dua pasar [makanan segar] terbesar berada di Auckland Selatan, jadi penutupan pembekal kecil-kecilan ini akan menyekat akses kepada pasar bagi mereka yang paling banyak berhadapan dengan isu sekuriti makanan. Harga makanan segar cenderung lebih rendah di pasar berbanding dengan harga di pasar raya. Sehubungan itu, ini bukan sahaja menjejaskan keluarga yang kini tidak lagi dapat membeli apa yang mereka boleh beli sebelumnya dengan harga pasar, tetapi ia turut menjejaskan pengeluar. Maka lebih ramai pengguna dan pengeluar akan meminta bantuan daripada bank makanan (Dombroski et al, 2020).

Faktor ketiga ialah kehilangan pekerjaan/sumber pendapatan dan peningkatan pekerja yang diminta untuk mengambil cuti tanpa gaji menyebabkan peningkatan kepada mereka yang bergantung pada perkhidmatan makanan kecemasan. Kumpulan ini berisiko besar semasa pandemik disebabkan oleh faktor ketidakmampuan mereka untuk mendapatkan bekalan makanan yang mencukupi serta berkhasiat. Kebanyakan masyarakat yang mendapat bantuan makanan dalam tempoh darurat merupakan isirumah yang ketua keluarga mereka kehilangan pendapatan disebabkan Covid-19 dan tidak pernah menggunakan perkhidmatan mereka sebelum ini yakni sebelum pandemik Covid-19 berlaku (Neuwelt-Kearns, 2020). Pengangguran di New Zealand dijangkakan meningkat kepada sekitar 9\% pada bulan September 2020 dengan pengurangan atau penutupan perniagaan yang mempengaruhi sebahagian besar warga New Zealand. Ramai yang diberhentikan kerja dan bagi yang masih bekerja, mereka berhadapan dengan pengurangan jam bekerja atau tahap gaji, lantas menghadapi penurunan dalam pendapatan tanpa pengurangan dalam kos kehidupan. Bahkan di antara mereka yang masih bekerja penuh sepanjang tempoh ini, gaji minimum tetap tidak mencukupi untuk memenuhi keperluan hidup. Agensi perkhidmatan sosial sering melaporkan tentang pelanggan mereka yang, walaupun bekerja sepenuh masa, masih bersusah-payah mendapatkan makanan dan keperluan asas lain setelah membayar kos perumahan (Neuwelt-Kearns, 2020).

Penduduk New Zealand yang terjejas disebabkan oleh sumber pendapatan yang rendah tidak mempunyai kapasiti untuk menyimpan stok makanan untuk mengurangkan pergerakan. Pada ketika Covid-19 muncul di New Zealand dan sebelum "lockdown", berlakunya pembelian panik di kalangan masyarakat apabila barisan yang panjang wujud di pasar raya di seluruh negara sebelum lockdown berlaku (RNZ, 23 Mac 2021). Banyak pasar raya kehabisan stok makanan terutamanya tepung gandum, 
makanan dalam tin dan pasta. Berkali-kali mesej yang sama disampaikan kepada rakyat jelata: tidak perlu menyimpan stok makanan, terdapat banyak makanan di New Zealand, namun pembelian panik tetap berlaku (Oshri \& Kotlarsky, 2020). Ini meningkatkan isu-isu berkaitan bekalan rantaian apabila pasar raya tidak dapat mengisi rak secepat mana ia dikosongkan. Maksudnya, kehabisan tepung di rak pasar raya bukan bermaksud New Zealand kehabisan tepung tetapi ia disebabkan pembekal kehabisan bungkusan, dan bergegas untuk membungkus tepung-tepung tersebut untuk memenuhi lonjakan permintaan bagi 1 atau $2 \mathrm{~kg}$ tepung (Mitchell, 2021).

Pembelian berlebihan atau sikap menyimpan stok semasa penularan COVID-19 berlaku disebabkan oleh beberapa faktor yang saling berkaitan. Ini termasuklah campur tangan kerajaan ke atas kesihatan awam yang akan mengekang tingkah laku dan amalan pengguna yang normal misalnya dari segi di mana, bila dan bagaimana untuk membeli; gangguan rantaian bekalan makanan; media sosial; dan pelaporan media yang disensasikan (Hall et al, 2020; Zhao \& Zhou, 2020; Kirk \& Rifkin, 2020, Arafat et al, 2020). Ciri Covid-19 yang penuh dengan ketidakpastian terutamanya berkaitan dengan impak sebenar terhadap kehidupan seharian dan keupayaan mengekalkan rutin yang sama semasa perintah berkurung juga tidak membantu dalam mengurangkan pembelian panik rakyat New Zealand (Oshri \& Kotlarsky, 2020).

Biarpun kerajaan New Zealand menasihatkan masyarakat untuk 'berbelanja secara normal' dan membeli apa yang mereka perlukan sahaja, golongan yang berkemampuan akan membeli dengan banyak dan menyimpan stok sementara golongan yang terjejas pendapatan pula tidak berupaya untuk mengakses bekalan makanan dan keperluan asas yang diperlukan. Pada waktu trend pembelian panik tidak lagi berlaku dan rak-rak di kebanyakan pasar raya diisi semula, warga New Zealand diminta untuk tidak terlalu kerap membeli-belah bagi mengurangkan perhubungan dengan orang lain. Ini tidak menjadi isu bagi golongan berkemampuan. Namun bagi mereka yang tidak dapat membeli barangan keperluan dengan banyak, mereka perlu mengunjungi pasar raya setiap kali menerima gaji atau sekerap yang boleh untuk membeli barangan makanan yang perlu sahaja.

Sebenarnya penyaluran bekalan dan pengedaran makanan melalui pasar raya, ditambah lagi dengan kehilangan pendapatan telah menghalang akses dari segi geografi dan kewangan. Bila ini digabungkan dengan sekatan pengangkutan awam dan permintaan tinggi terhadap perkhidmatan teksi dan Uber, ramai yang tidak dapat mengakses makanan dari pasar raya yang ada. Terdapat beberapa lokasi di New Zealand, termasuk bandar-bandar kecil dan kawasan luar bandar khususnya, tidak mempunyai perkhidmatan kereta sewa atau Uber, dan teksi juga amat terhad. Gabungan faktor-faktor ini telah memperburukkan isu ketidakseimbangan sedia ada dan menyebabkan permintaan yang mendadak terhadap perkhidmatan bank makanan dari mereka yang sebelum ini tidak layak atau tidak pernah menggunakan saluran ini untuk mendapat makanan. Ini termasuk mereka yang boleh membeli makanan tetapi yang merasa tidak selamat memasuki pasar raya, mereka yang tidak memiliki kenderaan peribadi dan tidak mampu menggunakan teksi swasta, dan pekerja asing dan pelajar antarabangsa yang diberhentikan oleh majikan mereka dan tidak layak mendapat bantuan kebajikan negeri atau sokongan rangkaian keluarga (Dombroski et al, 2020).

Dalam era pandemik Covid-19, lebih kurang 23\% Maori tinggal dalam isi rumah berpendapatan rendah dan mengalami isu sekuriti makanan. Bukan itu sahaja, perkembangan yang berlaku di New Zealand dari segi polisi-polisi kerajaan yang mengawal pergerakan menyebabkan ada yang dahulunya "food secure" kini menjadi "insecure". Ternyata akses kepada sumber makanan tradisional melalui perburuan dan penangkapan ikan, dan limitasi perjalanan untuk mendapatkan sumber-sumber segar yang murah (seperti di pasar komuniti) telah meletakkan kekangan yang berterusan kepada whānau. Ramai penduduk Maori tidak mempunyai masa untuk menyesuaikan diri dan merancang strategi untuk mengatasi situasi tersebut (Tunks, 2021).

Ini dibuktikan dengan peningkatan dan permintaan besar untuk bungkusan makanan dari kalangan penduduk Maori. Bantuan kewangan dari kerajaan dan dari tribal reserves menunjukkan bahawa Pembekal Perkhidmatan Sosial dan Kesihatan Maori dan juga badan bukan kerajaan dengan pantasnya telah memobilisasikan bantuan sebagai respons kepada keperluan terdesak tersebut. Produk makanan yang tipikal dimasukkan dalam bungkusan ini adalah seperti sup dalam tin, tomato dan kacang, pasta 
dan beras, mi, buah-buahan dalam tin, dan kadang kala bijirin dan roti. Biasanya makanan yang tinggi karbohidrat dan natrium amat diperlukan (Tunks, 2021). Ramai pemimpin Maori sendiri telah berusaha mengatur penghantaran bungkusan makanan untuk mengurangkan tekanan fizikal dan mental yang dibawa oleh wabak tersebut. Tindakan yang diambil oleh pemimpin penduduk peribumi ini dipuji oleh Jeffrey Campbell, mantan pengurus seksyen Forest and Farm Facility, FOA, di mana beliau menyatakan sistem makanan penduduk peribumi yang fungsional ini merupakan manifestasi semangat timbal balik, tindakan kolektif, dan saling mengambil berat di antara satu sama lain, dan harus menjadi model sasaran untuk semua pihak (Food Tank, November 2020). Namun demikian, walaupun bungkusan makanan menyediakan sokongan yang diperlukan kepada whānau, kelestarian kepada akses dan ketersediaan makanan perlu diambil kira supaya ketahanan penduduk Maori semakin tinggi dan tidak wujudnya kebergantungan kepada bungkusan makanan semata-mata.

Penularan pandemik Covid-19 telah menyebabkan kemiskinan kanak-kanak semakin meningkat disebabkan banyak keluarga dilanda kesukaran hidup bila ibu-bapa atau penjaga kehilangan pekerjaan atau kekurangan masa bekerja. Ternyata bantuan kerajaan banyak membantu tetapi bantuan yang diberikan tidak dapat mengimbangi impak ekonomi untuk jangka masa lama semasa lockdown dan kemelesetan global. Maka berlaku peningkatan kemiskinan bagi anak-anak yang berada dalam isi rumah yang miskin sebelum Covid-19, ditambah lagi dengan yang baru jatuh miskin akibat kehilangan pendapatan kerana Covid-19.

Bagi keluarga yang bergantung kepada program pemberian makanan di sekolah, penutupan sekolah memberi tekanan tambahan kepada keluarga ini. Gangguan lockdown bermaksud lebih ramai kanakkanak yang akan berlapar untuk tempoh masa yang panjang. Ketiadaan atau kekurangan sumber pendapatan untuk menyara diri mereka bermaksud keluarga akan bergantung kepada bantuan amal, menjadikan sumber makanan mereka semakin berkurangan(Child Poverty Action Group, 2020: 3). Walaupun sudah kembali ke sekolah, isu sekuriti makanan di kalangan kanak-kanak masih berlaku. Berdasarkan tinjauan yang dibuat ke atas $90 \%$ daripada 400 buah sekolah oleh KidsCan, yakni sebuah badan amal terkemuka di New Zealand yang membantu anak-anak yang terjejas dengan kemiskinan, didapati bahawa masalah sekuriti makanan sangat signifikan di kalangan kanak-kanak yang bersekolah. Sebelum Covid-19, seramai 30,000 kanak-kanak sekolah di seluruh New Zealand telah dibantu oleh KidsCan setiap hari. Namun selepas lockdown, jumlah meningkat kepada 40,000 setiap hari. Di daerah Wairapapa misalnya, makanan panas telah dibekalkan kepada kanak-kanak di 5 buah sekolah bagi keseluruhan empat sesi pengajian pada tahun 2020 berbanding dengan hanya di Sesi 2 dan 3 pada tahun lalu (NZ Herald, 2021).

\section{Kesimpulan}

Masalah sekuriti makanan sememangnya satu masalah yang berlaku secara global dan sedang dihadapi oleh sebilangan penduduk dunia. Penularan pandemik Covid-19 telah memburukkan lagi situasi ini. Dalam konteks negara New Zealand, masalah sekuriti makanan merupakan satu isu yang berlaku di New Zealand sebelum zaman pandemik Covid-19 lagi. Walaupun New Zealand merupakan antara pengeksport makanan dunia dan boleh memberi makan penduduknya dengan selesa, ternyata isu sekuriti makanan tetap menjadi perhatian kerajaan dalam tempoh dua dekad pertama abad ke-21. Sejak sebelum penularan Covid-19 lagi sebilangan penduduknya telah berhadapan dengan isu "akses" kepada makanan. Golongan yang terjejas ini termasuklah etnik Maori dan Pasifik, gelandangan, kanak-kanak, ibu/bapa tunggal, orang kurang upaya. Berlakunya pandemik Covid-19 yang menggegarkan dunia telah memberi impak signifikan kepada isu sekuriti makanan di New Zealand. Ciri penyakit yang membawa kepada kadar keberjangkitan dan kes kematian yang tinggi di peringkat global telah menyebabkan kerajaan New Zealand melaksanakan polisi yang bersifat "go hard and go early" yakni polisi penghapusan terus dan bukan sekadar polisi mitigasi "meratakan lekukan". Perlaksanaan sistem amaran tahap 4 yang mengenakan darurat (lockdown) telah mengawal pergerakan penduduk dan hanya membenarkan golongan berkepentingan (essential) sahaja untuk bekerja di luar dan memaksa rakyat lain untuk berada di rumah. 
Hampir satu perempat rakyat New Zealand memerlukan bantuan daripada pihak kerajaan dan badan bukan kerajaan melalui geran khas atau bank makanan demi menjamin kelangsungan hidup. Ramai yang mengalami kesukaran untuk mendapatkan akses bekalan makanan (food insecurity) untuk pertama kalinya. Pandemik Covid-19 telah menyebabkan ramai pekerja diberhentikan dan ada yang dipotong gaji atau dikurangkan jam bekerja kerana pengoperasian majikan terjejas, lantas memberi impak kepada sumber pendapatan. Kekurangan atau ketiadaan sumber pendapatan akibat pandemik Covid-19 telah membawa kepada masalah sekuriti makanan di peringkat kronik dan sederhana bagi mereka yang tiada wang untuk membeli makanan. Pandemik Covid-19 telah menunjukkan kelemahan yang ada pada sistem rantaian bekalan yang wujud dengan merujuk kepada berlakunya kekurangan produk penting disebabkan oleh pembelian panik dalam kalangan rakyat New Zealand dan kurangnya kerja-kerja pembungkusan yang dapat dilakukan oleh pengeluar. Ia juga telah menyebabkan kenaikan harga barangan terutamanya sayuran dan buah-buahan segar yang menjejaskan nutrisi. Penutupan pusat perniagaan kecil misalnya pasar segar dan kebergantungan kepada pasar raya dengan harga yang lebih mahal telah menyebabkan masalah sekuriti makanan di kalangan rakyat bertambah runcing. Faktor geografi, isu pengangkutan dan faktor sosio-budaya juga menjejaskan akses makanan oleh sebilangan penduduk.

Sehubungan itu, dapat dikatakan bahawa jumlah rakyat yang berhadapan dengan masalah sekuriti makanan di New Zealand meningkat dari sebelum era Covid-19 sehingga era pandemik Covid-19 berdasarkan kepada pergantungan mereka kepada bantuan dana dan bungkusan makanan. Secara total, intervensi daripada pelbagai pihak samada kerajaan atau swasta amat penting bagi menjamin kelestarian sekuriti makanan di kalangan rakyat.

\section{Penghargaan}

Kajian ini dibiayai oleh geran penyelidikan di bawah Skim Dana Khas (SDK0280-2020). Para penyelidik ingin merakamkan setinggi-tinggi penghargaan dan terima kasih kepada pihak Universiti Malaysia Sabah di atas pembiayaan penyelidikan ini.

\section{Rujukan}

Arafat, S.M.Y, Kar, S.K., Menon, V., Kaliamoorthy, C., Mukherjee, S., Alradie-Mohamed, A., Sharma, P., Marthoenis, M. \& Kabir, R. (2020). Panic buying: An insight from the content analysis of media reports during COVID-19 pandemic. Neurology, Psychiatry and Brain Research, 37, 100-3.

Baker, M.G., Wilson, N. \& Anglemyer, A. (August 2020). Successful Elimination of Covid-19 Transmission in New Zealand. The New England Journal of Medicine, 383(8). Massachusetts Medical Society. doi: 10.1056/NEJMc2025203. (diakses pada 14 April 2021).

Beavis, B.S. et al. (2019). Exploration of Maori household experiences of food insecurity. Nutrion and Dietics 2019. 76: 344-352.

Bowers, S., Carter, K., Gorton, D. et al. (2009). Enhancing food security and physical activity for Māori, Pacific and low-income peoples. Wellington: Clinical Trials Research Unit, University of Auckland; GeoHealth Laboratory, University of Canterbury; Health Promotion and Policy Research Unit, University of Otago; Te Hotu Manawa Māor. https://www.otago.ac.nz/heppru/ota go022605.pdf. (diakses pada 30 April 2021).

Carter, K. N., Lanumata, T., Kruse, K. \& Gorton, D. (2010). What are the determinants of food insecurity in New Zealand and does this differ for males and females? Australian and New Zealand Journal of Public Health, 34(6), 602-608. doi: https://sci-hub.do/http://dx.doi.org/10.111 1/j.1753-6405.2010.00615.x. (diakses pada 20 April 2021).

Cennimo, D.J. (2021). Coronavirus Disease 2019 (COVID-19). Medscape. 21 Mei. https://emedicine. medscape.com/article/2500114-overview. (diakses pada 14 Mei 2021).

Cousins, S. (2020). New Zealand eliminates COVID-19. The Lancet, 395. 9 Mei. https://www.thelan cet.com/action/showPdf?pii=S0140-6736\%2820\%2931097-7. (diakses pada 20 Mei 2021). 
Malaysian Journal of Social Sciences and Humanities (MJSSH), Volume 6, Issue 6, (page 1 - 17), 2021

DOI: https://doi.org/10.47405/mjssh.v6i6.832

Dombroski, K., Diprose, G., Sharp, E., Graham, R., Lee, L., Scobie, M., Richardson, S., Watkins, A., dan Martin-Neuninger, R. (2020). Food for People in Place: Reimagining Resilient Food Syatems for Economic Recovery. https:www.mdpi.com/journal/sustainability. (diakses pada 14 Mei 2021).

Food and Agriculture Organization of the United Nations (FAO). (2002). The State of Food Insecurity in the World. Rome.

Food and Agriculture Organization of the United Nations (FAO). (2006). The State of Food and Agriculture. Rom.

Food and Agriculture Organization of the United Nations (FAO). (2010) The State of Food Insecurity in the World. http://www.fao.org/docrep/013/i1683e/i1683e.pdf. (diakses pada 18 Mei 2021).

Food and Agriculture Organization of the United Nations (FAO). (2015). The State of Food Insecurity in the World. http://www.fao.org/3/a4ef2d16-70a7-460a-a9ac-2a65a533269a/i4646e.pdf. (diakses pada 20 Mei 2021).

Food and Agriculture Organization of the United Nations (FAO). (2019). The State of Food and Agriculture. Moving Forward on Food Loss and Waste Reduction. Rom. http://www.fao.org/3/ ca6030en/ca6030en.pdf. (diakses pada 21 Mei 2021).

FAO, IFAD, UNICEF, WFP and WHO. (2019). The State of Food Security and Nutrition in the World 2019. Safeguarding against economic slowdowns and downturns. Rome. http://www.fao.org/3/ca 5162en/ca5162en.pdf. (diakses pada 20 Mei 2021).

FIVIMS. (2003). Measurement and assessment of food deprevation and undernutrition. Rom FAO.

Food Tank. (Nov 2020). COVID-19 Endangers Indigenous Right to Food, Says U.N. Report. https://foodtank.com/news/2020/11/covid-19-endangers-indigenous-right-to-food-says-u-nreport/. (diakses pada 3 Mei 2021).

Fram. M.S., Ritchie, L.D., Rosen, N. et al. (2015). Child experience of food insecurity is associated with child diet and physical activity. Journal of Nutrition, 145(3), 499-504.

Government of New Zealand. (2020). "COVID-19: Further steps to protect New Zealanders' jobs". 27 Mac. https://www.beehive.govt.nz/release/covid-19-further-steps-protect-new-zealanders\%E2\% 80\%99-jobs. (diakses pada 20 April 2021).

Graham, R., Hodgetts, D., Stolte, O. \& Chamberlain, K. (2018) Hiding in Plain Sight: Experiences of Food Insecurity and Rationing in New Zealand. Food, Culture \& Society, 21(3), 384-401, doi: 10.1080/15528014.2018.1451043.

Graham, R. (2019). Aotearoa, land of the wide bare cupboard. Food Insecurity in New Zealand Part 2: Living with Hunger (How families manage when things are right). Child Poverty Action Group.

Graham-McLay, C. (2020). New Zealand drops Covid-19 restrictions after nation declared 'virus free'. https://www.theguardian.com/

Ghebreyesus, T.A. (2020). The Worst is Yet to Come. https://www.youtube.com/watch?v=11x6ZYQ_vg. (diakses pada 22 Mei 2021).

Grieser, S. (September 2020). Food Insecurity in New Zealand: A Hidden Reality. https://borgenproject.org/

Hall, M.C., Prayag, G., Fieger, P. \& Dyason, D. (2020). Beyond panic buying: Consumption displacement and COVID-19. Journal of Service Management, 32, 113-28.

Healy, A. dan Malhorta, N. (2009). Myopic Voters and Natural Disaster Policy. American Political Science Review, 103, 387-406.

Jamieson, T. (2020). "Go Hard, Go Early": Preliminary Lessons from New Zealand's Response to COVID-19. American Review of Public Administration, 50(6-7), 598-605. doi: 10.1177/0275074020941721. (diakses pada 28 Mei 2021).

Kaiser, M., Himmelheber, S., Miller, S., \& Heyward, A. (2015). Cultivators of Change: Food Justice in Social Work Education. Social Work Education, 34(5), 544-57.

Kira, G. (2020). Food insecurity for Māori is getting worse. Here are some ways we can all help. 17 April. https://thespinoff.co.nz/atea/17-04-2020/food-insecurity-for-maori-is-getting-worse-hereare-some-ways-we-can-all-help/. (diakses pada 20 Mei 2021).

Kirk, C.P., \& Rifkin, L.S. (2020). I'll trade you diamonds for toilet paper: Consumer reacting, coping and adapting behaviors in the COVID-19 pandemic. Journal of Business Research, 117, 124-31.

Last, J.M. (1988). A dictionary of epidemiology. 2nd ed. Oxford: Oxford University Press.

Martinez, M. \& Kawam, E. (2014). A Call to Action for Social Workers: Food Insecurity and Child Health. Social Work, 59(4), 370-2. 
Malaysian Journal of Social Sciences and Humanities (MJSSH), Volume 6, Issue 6, (page 1 - 17), 2021

DOI: https://doi.org/10.47405/mjssh.v6i6.832

McLean, E. (2020). NZ 35th in pandemic preparedness. 16 Februari. https://www.odt.co.nz/news/dune din/nz-35th-pandemic-preparedness. (diakses pada 11 Mei 2021).

McLaughlin, K.A., Green, J.G., Alegria, M., Costello, J., Gruber, M., Sampson, N. \& Kessler, R.C. (2012). Food Insecurity and Mental Disorders in a National Sample of U.S. Adolescents. Journal of the American Academy of Child \& Adolescent Psychiatry, 51(12), 1293-303.

Mitchell, P. (2021). Protecting Aotearoa's food supply in wake of Covid-19. 31 Januari. https://www. stuff.co.nz/national/300217606/protecting-aotearoas-food-supply-in-wake-of-covid19. (diakses pada 17 Mei 2021).

Ministry of Health, New Zealand. (2019). Household Food Insecurity Among Children in New Zealand. Wellington: Ministry of Health.

Ministry of Health, New Zealand. (2021). 27 Mei.

Ministry of Social Development. (2020). Covid-19 Reporting. https://www.msd.govt.nz/about-msdand-our-work/publications-resources/statistics/covid-19/index.html. (diakses pada 23 Mei 2021).

Morens, D.M., Folkers, G.K., Fauci, A.S. (2009). What Is a Pandemic? The Journal of Infectious Diseases. 200(7): 1018-1021. https://doi.org/10.1086/644537. (diakses pada 1 Jun 2021).

Neuwelt-Kearns, C. (2020). Aotearoa, land of the wide bare cupboard. Food Insecurity in New Zealand Part 6: An outbreak of hunger (the spread of food insecurity in atime of Covid-19). Child Poverty Action Group.

New Zealand Government. Essential Businesses. 2020. https://covid19.govt.nz/businesses-and-employ ees/essential-businesses/. (diakses pada 20 Mei 2021).

NZ Herald. (17 Februari 2021). Covid-19 coronavirus: Food insecurity an issue at Wairarapa schools. https://www.nzherald.co.nz/nz/covid-19-coronavirus-food-insecurity-an-issue-at-wairarapa-schoo ls/KD6KVDHPMTZSPM2VFPVFWBZU44/. (diakses pada 13 Mei 2021).

Oshri, Ilan \& Kotlarsky, J. (2020). How COVID-19 is disrupting the food supply chain in New Zealand". 25 Mac. https://www.cio.com/article/3534052/how-covid-19-is-disrupting-the-foodsupply-chain-in-new-zealand.html. (diakses pada 20 Mei 2021).

Food Security in a Pandemic. (tiada tarikh). https://www.paho.org/disasters/dmdocuments/RespTool Kit_14_Tool\% 2007_FoodSecurityinaPandemic.pdf. (diakses pada 11 April 2021).

Pal, A. (2021). WIDER IMAGE In COVID-hit India, a 26-year-old doctor decides who lives and who dies. 5 Mei. https://www.reuters.com/world/asia-pacific/wider-image-covid-hit-india-26-year-olddoctor-decides-who-lives-who-dies-2021-05-05/. (diakses pada 20 Mei 2021).

Poata-Smith, E. (2013). Inequality and Maori. In: Rashbrooke M. (ed.). Inequality: A New Zealand Crisis. Wellington: Bridget Wil-liams Books. 148-58.

Perry, B. (2018). Household Incomes in New Zealand: Trends in indicators of inequality and hardship 1982 to 2017. Wellington: Ministry of Social Development.

Radio New Zealand (RNZ). (2021). Panic buying and generosity: A year since NZ headed into Covid19 lockdown. 23 Mac https://www.rnz.co.nz/news/national/438934/panic-buying-and-generositya-year-since-nz-headed-into-covid-19-lockdown. (diakses pada 20 Mei 2021).

Reeves, M.P. (1913). Round about a Pound a Week. Prabhat Prakashan.

Rice, G.W. (2020). How reminders of the 1918-19 pandemic helped Australia and New Zealand respond to Covid-19. Journal of Global History, 15(3), 421-433.

Relman, D.A., Choffnes, E.R., Mack, A. (2010). The Domestic and International Impacts of the 2009H1N1 Influenza A Pandemic: Global Challenges, Global Solutions: Workshop Summary. Institute of Medicine, Board on Global Health, Forum on Microbial Threats. National Academies Press,

Robert, A. (Dec 2020). Lessons from New Zealand's COVID-19 outbreak response. The Lancet. 5(11): e569-e570. doi:https://doi.org/10.1016/S2468-2667(20)30237-1. (diakses pada 11 Mei 2021).

Robson, S. (2020). "Covid-19 lockdown: Nearly 30,000 more people on jobseeker benefit". RNZ. 25 April. https://www.rnz.co.nz/news/national/415038/covid-19-lockdown-nearly-30-000-more-peo ple-on-jobseeker-benefit

Robson, S. (2021). Salvation Army calls for 'brave policy action' to stem increasing inequality. RNZ. 17 February. https://www.rnz.co.nz/news/national/436543/salvation-army-calls-for-brave-policyaction-to-stem-increasing-inequality. (diakses pada 14 April 2021).

Roy, E.A. (2020). 'Go hard, go early' - now New Zealand goes back to the drawing board. The Guardian. 15 Ogos. https://www.theguardian.com/world/2020/aug/16/go-hard-go-early-now-newzealand-goes-back-to-the-drawing-board. (diakses pada 20 Mei 2021). 
Rush, E. A. (2019). Land of the Long Wide Bare Cupboard. Part 1: Fat, Famished or Starved in a Land of Plenty? https://www.cpag.org.nz/campaigns/the-latest-aotearoa-land-of-the-long-wide/. (diakses pada 11 Mei 2021).

Rush, E \& Rusk, I. (2009). Food security for Pacific peoples in New Zealand. Wellington: Obesity Action Coalition.

Sassi, Maria. (2018). Understanding Food Insecurity. Switzerland: Springer International Publishing.

Scudellari, M. (2020). How the pandemic might play out in 2021 and beyond. Nature. 584:22-25 5 Ogos. https://www.nature.com/articles/d41586-020-02278-5. (diakses pada 29 Mei 2021).

Statistics New Zealand. Food Price Index: (Jun 2020). https://www.stats.govt.nz/information-releases/ food-price-index-june-2020. (diakses pada 11 Mei 2021).

Statistics New Zealand. (2020). New Zealand's population passes 5 million. 18 Mei. https://www.stats. govt.nz/news/new-zealands-population-passes-5-million. (diakses pada 20 Mei 2021).

Stockman, J. (2021). How New Zealand eliminated COVID-19. 4 Januari. https://blogs.lse.ac.uk/covid 19/2021/01/04/how-new-zealand-eliminated-covid-19/. (diakses pada 13 April 2021).

Tatauranga Aotearoa Stats NZ. (2020). Unemployment rate hits 5.3 percent due to COVID-19. 4 November. https://www.stats.govt.nz/news/unemployment-rate-hits-5-3-percent-due-to-covid-19.

Taubenberger, J.K. (2006). 1918 Influenza: The Mother of All Pandemics. National Emergency Training Center,

Thomson, A. \& M. Metz. (1999). Implications of Economic Policy for Food Security: A Training Manual. http://www.fao.org/3/x3936e/X3936E00.htm. (Diakses pada 28 Mei 2021).

Tunks, Megan. (2021). From Food Insecurity to Food Security. https://toitangata.co.nz/2020/06/23/me gan-tunks-from-food-insecurity-to-food-security/. (diakses pada 19 Mei 2021).

United Nations System Standing Committee on Nutrition (UNSCN). (Mac 2020). The COVID-19 pandemic is disrupting people's food environments: a resource list on Food Systems and Nutrition responses. https://www.unscn.org/en/news-events/recent-news?idnews=2039

Utter, J., S. Denny, Robinson, E. et al. (2012). Food security concerns among young people: Impact on eating behaviors and weight status. Journal of Hunger and Environmental Nutrition, 7(1), 10111.

Waka Kotahi NZ Transport Agency. (2019). Keeping Cities Moving. https://www.nzta.govt.nz/assets/ resources/keeping-cities-moving/Keeping-cities-moving.pdf (diakses pada 14 April 2021).

Warr, P. (2014) Food Insecurity and Its Determinants. The Australian Journal of Agricultural and Resource Economics, 58, 519-37.

Whitaker, R. Phillips, S. \& Orzol, S. (2006). Food insecurity and the risks of depression and anxiety in mothers and behavior problems in their school-aged children. Pediatrics, 118(3), e859-68.

World Health Organization (WHO). (2021). 5 Mei. https://covid19.who.int/. (diakses pada 20 Mei 2021).

World Bank. (2021). Food Security and COVID-19. 21 Mei. https://www.worldbank.org/en/topic/agri culture/brief/food-security-and-covid-19. (diakses pada 20 Mei 2021).

World Food Programme. (2015). Hunger. https://www.wfp.org/hunger/what-is.

Yousafzai, A.K, Rasheed, M.A. \& Bhutta, Z.A. (2013). Annual research review: improved nutritionpathway to resilience. J Child Psychol Psychiatry, 54:367-77. doi: 10.1111/jcpp.12019 . (diakses pada 19 Mei 2021).

Zhao, N. \& Guangyu, Z. (2020). Social media use and mental health during the COVID-19 pandemic: Moderator role of disaster stressor and mediator role of negative affect. Applied Psychology: Health and Well-Being, 12, 1019-38. 